\title{
ANALISIS RESIKO KEUANGAN DENGAN MODEL ALTMAN Z- SCORE PADA PERUSAHAAN PERBANKAN DI INDONESIA (Listed di Bursa Efek Indonesia)
}

\author{
Hermin Nainggolan SE.,MM \\ Program Studi Manajemen \\ Sekolah Tinggi Ilmu Ekonomi Balikpapan (STIEPAN) \\ Herminnainggolan0201@gmail.com
}

\begin{abstract}
ABSTRAK
Penelitian ini dilakukan untuk mengetahui dan menganalisis resiko kebangkrutan perusahaan perbankan pemerintah dan swasta yang terdaftar di Bursa Efek Indonesia menurut Altman Z-Score serta untuk mengetahui dan menganalisis perbankan yang terdaftar di Bursa Efek Indonesia yang memiliki tingkat resiko kebangkrutan paling besar. Penelitian ini menganalisis laporan keuangan 10 bank yang terdaftar di Bursa Efek Indonesia tahun 2006-2016 berdasarkan assets terbesar pada tahun 2016 dan telah menjual sahamnya di Bursa Efek Indonesia sejak tahun 2005. Berdasarkan hasil analisis data dapat disimpulkan bahwa seluruh perusahaan perbankan yang menjadi objek penelitian dikategorikan mengalami ancaman kebangkrutan karena nilai cut-off di bawah 1,81 dan Bank Permata memiliki tingkat resiko kebangkrutan paling besar dengan nilai $Z$-Score rata-rata sebesar 0,288 .
\end{abstract}

Kata kunci: Perbankan, Altman Z-Score, cut-off

\begin{abstract}
The purpose of this study is to determine and analyze the risk of bankruptcy of government and private banking companies listed in Indonesia Stock Exchange by Altman Z-Score and to know and analyze the banks listed in Indonesia Stock Exchange which has the highest risk of bankruptcy. This study analyzes the financial statements of 10 banks listed in Indonesia Stock Exchange 2006-2016 based on the largest assets in 2016 and has sold its shares in Indonesia Stock Exchange since 2005. Based on the data analysis it can be concluded that all banking companies that become the object of research are categorized suffered the threat of bankruptcy due to a cut-off value below 1,81 and Bank Permata had the highest risk of bankruptcy with an average Z-Score of 0.288 .
\end{abstract}

Keywords: Banking, Altman Z-Score, cut-off 


\section{PENDAHULUAN}

\section{Latar Belakang}

Perbankan mempunyai peran penting di dalam kehidupan masyarakat. Bank juga dianggap sebagai penggerak roda perekonomian suatu negara karena fungsi dari bank sendiri sangat vital. Misalnya menciptakan peredaran uang sebagai penunjang kegiatan usaha, tempat menyimpan uang, melakukan pembayaran atau penagihan, dan masih banyak lagi fungsi yang lainnya dari bank.

Sebagai salah satu lembaga keuangan, bank sangatlah perlu mengetahui tingkat resiko keuangan suatu bank agar dapat beroperasi secara maksimal. Dalam persaingan di dunia perbankan yang semakin banyak dan berkualitas harus diimbangi dengan manajemen yang baik pula.

Analisis resiko keuangan sangat membantu manajemen dalam mengetahui kinerja bisnisnya. Sebelum menganalisis keuangan dan risiko terlebih dahulu mengetahui kelemahan perusahaan serta hasil yang dikira cukup baik dan mengetahui kebangkrutan perusahaan tersebut. Untuk meningkatan produktifitas perusahaan harus mengetahui kesehatan suatu perusahaan, sehingga mampu memperoleh keuntungan untuk menghindari adanya potensi kebangkrutan.

Dengan banyaknya macam model yang dapat digunakan untuk memprediksi potensi kebangkrutan, salah satu metode yang digunakan dalam risiko keuangan adalah metode Altman Z-Score. Model Altman Z-Score merupakan suatu model analisis yang digunakan untuk memprediksi potensi kebangkrutan perusahaan dengan tingkat ketepatan yang relatif bisa dipercaya. Oleh karena itu, analisis ini dapat digunakan untuk mengukur tingkat resiko keuangan dari perusahaan.

Pada penelitian ini akan dibahas mengenai prediksi kebangkrutan bank dengan menggunakan model Altman Z-Score yang di dalamnya terdapat rasiorasio keuangan diantaranya rasio likuiditas diproksikan dengan Working Capital to Total Assets, rasio profitabilitas diproksikan dengan Return on Total Assets dan Retained Earnings to Total Assets, serta rasio aktivitas diproksikan dengan Equity to Debt dan Sales to Total Assets.

Data dari 43 perusahaan perbankan yang terdaftar di Bursa Efek Indonesia, peneliti membandingkan aset terbesar pada akhir periode 31 Desember 2016. Laporan posisi keuangan menyatakan bahwa 10 perusahaan perbankan dengan aset terbesar pada tahun 2016, ada yang mengalami kenaikan maupun penurunan.

Berdasarkan latar belakang yang telah diuraikan di atas, penulis mengambil judul "Analisis Resiko Keuangan dengan Model Altman Z-Score pada Perusahaan Perbankan di Indonesia (Listed di Bursa Efek Indonesia)".

\section{Rumusan Masalah}

1. Apakah menurut Altman ZScore, perusahaan perbankan pemerintah dan swasta yang terdaftar di Bursa Efek Indonesia memiliki resiko kebangkrutan? 
2. Manakah diantara perusahaan perbankan pemerintah dan swasta yang terdaftar di Bursa Efek Indonesia tersebut yang memiliki tingkat resiko kebangkrutan paling besar?

\section{Tujuan Penelitian}

1. Untuk mengetahui dan menganalisis resiko kebangkrutan perusahaan perbankan pemerintah dan swasta yang terdaftar di Bursa Efek Indonesia menurut Altman Z-Score.

2. Untuk mengetahui dan menganalisis perbankan yang terdaftar di Bursa Efek Indonesia yang memiliki tingkat resiko kebangkrutan paling besar.

\section{Manfaat Penelitian}

1. Bagi investor dan calon investor, diharapkan dapat memberikan gambaran terhadap perkembangan perusahaan yang berkaitan dengan masalah keuangan yang dijadikan acuan pengambilan keputusan.

2. Bagi perusahaan yang bersangkutan, diharapkan penelitian ini dapat dijadikan sebagai referensi atau masukan untuk kebijakan-kebijakan perusahaan pada periode-periode selanjutnya.

3. Bagi pihak-pihak lain, diharapkan hasil penelitian dapat bermanfaat untuk menambah pengetahuan serta menjadi referensi atau bahan masukan dalam penelitian serupa pada penelitian yang akan datang.

4. Bagi penulis, diharapkan penelitian ini dapat menambah

\begin{abstract}
pengetahuan dalam bidang manajemen keuangan dengan cara memakai model prediksi kebangkrutan dalam pelaksanaannya di dunia nyata dan sebagai salah satu persyaratan untuk memperoleh gelar Sarjana Ekonomi (S-1) Program Studi Manajemen pada Sekolah Tinggi Ilmu Ekonomi Balikpapan (STIEPAN).
\end{abstract}

\section{TINJAUAN PUSTAKA}

\section{Penelitian Terdahulu}

1. Altman (1968) memprediksi kebangkrutan dengan menggunakan metode $M D A Z$ Score dan mampu memprediksi hingga keakuratannya mencapai 95\% pada perusahaan selama 12 bulan. Pengujian lain dilakukan lagi oleh Altman dengan mengambil beberapa sampel perusahaan dengan iklim ekonomi yang berbeda-beda dan tingkat keakuratan dari pengujian tersebut adalah $82 \%$ sampai dengan $85 \%$.

2. Endri (2009) melakukan penelitian dengan menggunakan analisis potensi kebangkrutan metode Altman sebagai alat analisis datanya. Dari hasil perhitungan, menunjukkan bahwa Bank Muamalat Indonesia (BMI) termasuk dalam kategori bangkrut. Hal ini dapat dilihat dari Z-Score-nya lebih kecil dari 1,81. Jika ditelusuri satu persatu dari variabel di atas, nilai pada tiap variabel sangat kecil. Pada variabel $\mathrm{X}_{1}$ (net working capital/total assets) angkanya sangat kecil berkisar dari 0,03- 
0,06. Hal ini disebabkan rendahnya net working capital pada BMI.

3. Sudiyatno dan Puspitasari (2010) melakukan analisis keuangan menggunakan Altman Z-Score sebagai bagian dari indikator kinerja perusahaan juga dalam perhitungannya membutuhkan data keuangan yang disajikan melalui laporan keuangan perusahaan. Pada studi awal tahun 1968, Altman menggunakan sebuah cut-off ZScore sebesar 2,675, dengan kata lain, jika Z-Score berada di bawah cut-off line $(2,675)$, maka perusahaan diklasifikasikan sebagai perusahaan yang bangkrut atau dalam kondisi menuju kebangkrutan, dan jika berada di atas cut-off line diklasifikasikan sebagai perusahaan yang tidak bangkrut atau dalam kondisi sehat. Hal ini memungkinkan untuk mengklasifikasikan $94 \%$ sebagai perusahaan yang bangkrut, dan 97\% sebagai perusahaan yang tidak bangkrut satu tahun sebelum dinyatakan bangkrut.

4. Likumahua (2013) melakukan analisis dari data laporan keuangan perusahaan perbankan baik perbankan yang bangkrut dan perbankan yang tidak bangkrut. Data atau hasil perhitungan rasio-rasio tersebut, kemudian dianalisis lebih jauh dengan multivariate discriminant analysis menggunakan rasio-rasio yang ada dalam metode $Z$-Score yang ditemukan Altman, yaitu: $Z=$ $0,717 \mathrm{X}_{1}+0,847 \mathrm{X}_{2}+3,107 \mathrm{X}_{3}+$ $0,420 \mathrm{X}_{4}+0,998 \mathrm{X}_{5}$. Berdasarkan hasil perhitungan Z-Score pada perusahaan perbankan di Bursa Efek Indonesia, nilai Z-Score tertinggi pada tahun 2008 diperoleh PT. Bank Agro Niaga, Tbk sebesar 0,515, tahun 2009 diperoleh PT. Bank Mutiara, Tbk sebesar 1,535, pada tahun 2010 diperoleh PT. Bank Mega, Tbk sebesar 0,219, dan pada tahun 2011 diperoleh PT. Bank Ekonomi, Tbk sebesar 0,443. Sedangkan nilai Z-Score terrendah tahun 2008 diperoleh PT. Bank Mutiara, Tbk sebesar 5,113, pada tahun 2009 dan 2010 diperoleh berturut-turut oleh PT. Bank Bumi Putera, Tbk sebesar 0,080 dan 0,004, dan pada tahun 2011 diperoleh PT. Bank Mutiara, Tbk sebesar 0,004 . Sehingga semua bank masuk dalam kategori perusahaan yang berpotensi bangkrut.

5. Lisdayanti, dkk (2013) melakukan penelitian dengan menggunakan metode analisis Altman Z-Score. Populasi dari penelitian ini adalah 33 bank yang terdaftar di BEI pada tahun 2012 dengan 31 bank sebagai sampelnya. Persamaan Z-Score yang digunakan merupakan formula yang telah dikembangkan hingga dapat memprediksi kebangkrutan perusahaan non-manufaktur oleh Altman dan digunakan dalam penelitian ini: (Putri, 2013) $Z=$ $6,56 X_{1}+3,26 X_{2}+6,72 X_{3}+$ $1,05 \mathrm{X}_{4}$. Dari perhitungan yang telah dilakukan, maka potensi kebangkrutan dengan model Altman Z-Score pada bank yang terdaftar di BEI tahun 2012 
menunjukkan bahwa terdapat 12 bank yang mengalami kebangkrutan serius, 18 bank berada di grey area, dan 1 bank (Bank Bumi Arta Tbk) berada dalam kondisi keuangan yang sehat.

6. Sherbo dan Smith (2013) melakukan penelitian untuk menguji validitas model kebangkrutan Z-Score yang telah berusia 45 tahun. Z-Score adalah kombinasi linear dari lima rasio umum bisnis yang dihitung dengan koefisien berbeda dan dihitung dengan membandingkan data perusahaan yang telah menyatakan kebangkrutan dengan sampel pencocokan perusahaan yang sehat. Sesuai dengan formulasi asli Altman ZScore, $Z=1,2 \mathrm{X}_{1}$ (WCTA) + $1,4 \mathrm{X}_{2}($ RETA $)+3,3 \mathrm{X}_{3}($ EBITTA $)$ $+0,6 \mathrm{X}_{4}(M V E / B V T D)+1,0 \mathrm{X}_{5}$ (STA). Laporan hasil Z-Score, serta persentase perusahaanperusahaan di mana perhitungan $Z$-Score adalah < 1,81 dan diprediksi dengan benar masalah kebangkrutan. Selain itu, hasil laporan di mana Altman Z-Score $>$ 2,99 adalah diprediksi nonbangkrut. Ditemukan bahwa ZScore dua tahun sebelum kebangkrutan, dengan memprediksi 21 dari 33 perusahaan yang bangkrut, atau 64 persen.

7. Kusdiana (2014) melakukan penelitian untuk memprediksi tingkat kebangkrutan perusahaan dengan menggunakan variabelvariabel Altman's Z-Score. Kinerja bank selama lima tahun (2007-2011), menunjukkan kondisi keuangan perbankan berada pada tahap probabilitas kebangkrutan tinggi dibuktikan dengan Z"Scores sebesar 0,6909, hal ini disebabkan nilai dari masing-masing variabel meskipun bernilai positif namun masih sangat relatif kecil nilainya. Tingkat ketepatan model prediksi kebangkrutan Altman's Z"-Score selama lima tahun (2007-2011) sebesar $100 \%$ dengan tingkat kesalahan I (false negative) dan tipe kesalahan II (false positive) sebesar 0\%.

8. Kurniawati dan Kholis (2015) melakukan penelitian untuk perusahaan perbankan yang telah go public dengan metode Altman Z-Score Modifikasi dengan sampel perusahaan yang bangkrut sebanyak 15 perusahaan dengan prosentase akurasi $27,27 \%$, sedangkan 40 perusahaan tidak bangkrut dengan prosentase keakuratan sebesar $72,73 \%$.

9. Prabowo dan Wibowo (2015) menganalisis prediksi delisting perusahaan dengan menggunakan metode Altman ZScore, Zmijewski, dan Springate. Data yang digunakan dalam penelitian ini adalah data sekunder yang diperoleh dari Bursa Efek Indonesia pada tahun buku 2008-2013. Salah satu variabel independen dalam penelitian ini merupakan model Altman Z-Score. Model ini diukur dengan menggunakan persamaan di bawah ini: $Z=1.2$ $W C T A+1.4$ RETA +3.3 EBITTA + 0.6 MVEBVD + 1 $S A T A$. Berdasarkan tabel metode 
Altman terlihat bahwa dari total sampel 60 perusahaan yang sebenarnya Delisted, model Altman Z-Score memprediksi 43 perusahaan yang mengalami Delisted dan 17 perusahaan yang mengalami Listed. Sedangkan dari 60 perusahaan yang pada kenyataannya dikategorikan Listed, model Altman Z-Score memprediksi 42 perusahaan yang Listed dan 18 lainnya Delisted. Secara keseluruhan bahwa model Altman memiliki jumlah prediksi benar.

10. Utami dan Susanti (2015) melakukan penelitian untuk memprediksi potensi kebangkrutan pada perusahaan perbankan (Bank BCA dan Bank BNI) dengan model Altman ZScore. Formula Z-Score sebagai berikut: $Z=1,2$ (WCTA) $+1,4$ $($ RETA $)+3,3$ (EBITTA $)+0,6$ $(M V E B V L)+1$ (STA) (Weston \& Copeland, 2010:288). Nilai ZScore berdasarkan tahun 2011 $(0,7923), 2012 \quad(0,6863)$, dan 2013 (0,6956) menunjukkan bahwa Bank BNI sedang mengalami masalah kebangkrutan jika dilihat dari rasio RETA, karena perusahaan tidak mampu mengelola asset dengan baik sehingga tidak bisa memaksimalkan pendapatan. Sedangkan pada Bank BCA juga mengalami masalah serius (dalam zona merah). Nilai $Z$ Score tahun 2011 (0,724309), 2012 (0,7351), dan 2013 $(0,7243)$. Sama halnya dengan Bank BNI, Bank BCA juga mengalami kebangkrutan dikarenakan rendahnya nilai rasio RETA.

\section{Landasan Teori}

Pengertian Bank

Undang-Undang Republik Indonesia Nomor 10 Tahun 1998 tentang "Perbankan" menyebutkan bahwa bank adalah badan usaha yang menghimpun dana dari masyarakat dalam bentuk simpanan dan menyalurkannya kepada masyarakat dalam bentuk kredit dan/atau bentuk-bentuk lainnya dalam rangka meningkatkan taraf hidup rakyat banyak.

Perbankan dapat diartikan sebagai "segala sesuatu yang menyangkut bank, mencakup kelembagaan, kegiatan usaha, serta cara dan proses dalam melaksanakan kegiatan usahanya" (Darmawi, 2014:1).

\section{Laporan Keuangan Bank}

Ikatan Akuntan Indonesia (2015) dalam Pernyataan Standar Akuntansi Keuangan No. 1 menyatakan bahwa laporan keuangan adalah suatu penyajian terstruktur dari posisi keuangan dan kinerja keuangan suatu entitas. Tujuan laporan keuangan adalah memberikan informasi mengenai posisi keuangan, kinerja keuangan, dan arus kas entitas yang bermanfaat bagi sebagian besar kalangan pengguna laporan dalam pembuatan keputusan ekonomi.

\section{Resiko Keuangan}

Resiko dihubungkan dengan kemungkinan terjadinya akibat buruk (kerugian) yang tak diinginkan, atau tak terduga. Dengan kata lain, "kemungkinan itu sudah menunjukkan adanya ketidakpastian. Ketidakpastian itu merupakan kondisi yang menyebabkan 
tumbuhnya resiko" (Darmawi, 2016:23).

Kurniawati

menyatakan bahwa yang dimaksud dengan resiko keuangan di sini adalah masalah kebangkrutan. "Kebangkrutan (bankruptcy) biasanya diartikan sebagai kegagalan perusahaan dalam menjalankan operasi perusahaan untuk menghasilkan laba. Pernyataan kebangkrutan adalah masalah hukum yang timbul karena kreditur atau pihak tertentu mengajukan gugatan kebangkrutan”.

\section{Model Prediksi Kebangkrutan Altman Z-Score}

Analisis Z-Score adalah skor yang ditentukan dari hitungan standar kali nisbah-nisbah keuangan yang menunjukkan tingkat kemungkinan kebangkrutan perusahaan. Formula Z-Score untuk memprediksi kebangkrutan dari Altman merupakan sebuah multivariate formula yang digunakan untuk mengukur kesehatan finansial dari sebuah perusahaan. Altman menemukan lima jenis rasio keuangan yang dapat dikombinasikan untuk melihat perbedaan antara perusahaan yang bangkrut dan yang tidak bangkrut.

Pada tahun 1968, Altman berhasil menemukan model prediksi kebangkrutan yang pertama dan model ini dinamai Model Altman (ZScore). Alat ukur atau persamaan yang dipakai dalam analisis prediksi kebangkrutan model Altman adalah (Bragg, 2002:99):

$$
\begin{array}{r}
Z=1,2 X_{1}+ \\
3,3 X_{2}+1,4 X_{3}+0,6 X_{4}+0,999 X_{5}
\end{array}
$$

Keterangan:

$\mathrm{Z}=$ bankruptcy index
$\mathrm{X}_{1}=$ working capital / total asset

$\mathrm{X}_{2}=$ earnings before interest and

taxes / total asset

$\mathrm{X}_{3}=$ retained earnings / total asset

$\mathrm{X}_{4}=$ market value of equity to book value of total debt

$\mathrm{X}_{5}=$ sales $/$ total asset

Nilai $Z$ adalah indeks keseluruhan fungsi multiple discriminant analysis, di mana terdapat angka-angka cut off nilai $Z$ yang mewakili nilai suatu perusahaan apakah perusahaan akan mengalami kebangkrutan atau tidak pada masa mendatang dan Altman membaginya ke dalam tiga kategori, yaitu:

a. Jika nilai $Z<1,8$ maka termasuk perusahaan yang bangkrut.

b. Jika nilai $1,8<Z<2,99$ maka termasuk grey area (tidak dapat ditentukan apakah perusahaan sehat ataupun mengalami kebangkrutan).

c. Jika nilai $Z>2,99$ maka termasuk perusahaan yang tidak bangkrut atau sehat.

\section{Rasio-rasio Model Prediksi Kebangkrutan Altman Z-Score}

Penelitian yang dilakukan

oleh Altman dengan metode multivariate discriminant analysis, menggunakan rasio-rasio keuangan sebagai indikasi adanya kebangkrutan dan ketidakbangkrutan. Hasil penelitian tersebut kemudian dikenal dengan nama metode Z-Score. Sedangkan rasio-rasio keuangan yang digunakan dalam penelitian tersebut adalah sebagai berikut:

1. Working Capital to Total Assets Lukviarman dan Ramadhani (2009) menyatakan bahwa yang dimaksud Working 
Capital to Total Assets merupakan rasio likuiditas yang membandingkan aset likuid bersih dengan total aset. Aset likuid bersih atau modal kerja didefinisikan sebagai total aset lancar dikurangi total liabilitas lancar. Umumnya, bila perusahaan mengalami kesulitan keuangan, modal kerja akan turun lebih cepat daripada total aset menyebabkan variabel ini turun. Rasio ini menunjukkan kemampuan bank untuk menghasilkan modal kerja bersih dari keseluruhan aset yang dimilikinya. Modal kerja yang dimaksud di sini adalah selisih antara aset lancar (current assets) dengan liabilitas lancar (current liabilities). Sedangkan current assets pada perusahaan perbankan terdiri dari kas, investasi, dan lain-lain. Current liabilities terdiri dari kewajiban segera, simpanan nasabah, simpanan dari bank lain, efek, kewajiban deriveratif dan akseptasi, hutang pajak. Sedangkan total assets adalah semua aset yang ada di dalam perusahaan tersebut.

2. Return on Total Assets

Husnan dan Pudjiastuti (2015:78) menyatakan bahwa Return on Total Assets atau Return on Assets (ROA) menghitung berapa banyak laba bersih setelah pajak dihasilkan oleh total aset yang dimiliki perusahaan. Rasio ini banyak yang menghitung meskipun ada ketidaktepatan ketika kita membandingkan antara laba bersih setelah pajak (berarti laba operasi sudah dikurangi biaya bunga dan pajak penghasilan) yang sebenarnya merupakan hak pemilik ekuitas - dengan total aset (yang sebagian diantaranya mungkin dibiayai dengan utang).

3. Retained Earnings to Total Assets

Utari dkk (2014:163) memberikan penjelasan bahwa laba ditahan lahir dari laba bersih yang tidak dibagikan kepada pemegang saham. Laba ditahan terhadap total harta (retained earnings to total assets) digunakan untuk mengukur profitabilitas kumulatif. Rasio ini mengukur akumulasi laba selama perusahaan beroperasi”.

\section{Equity to Debt}

Rasio ini merupakan rasio yang digunakan untuk mengukur seberapa banyak aset perusahaan dapat turun nilainya sebelum jumlah utang lebih besar daripada asetnya dan perusahaan menjadi pailit. Modal yang dimaksud adalah gabungan nilai pasar dari modal biasa dan saham preferen (market value of common stock + preferred stock), sedangkan liabilitas mencakup liabilitas lancar dan liabilitas jangka panjang.

5. Sales to Total Assets

Penjualan terhadap total harta (sales to total assets) digunakan untuk mengukur kemampuan manajemen dalam menghadapi kondisi persaingan. Rasio tersebut mengukur kemampuan manajemen dalam menggunakan aset untuk menghasilkan penjualan. 


\section{Kerangka Berpikir}

\section{BEI}

Laporan Keuangan Perusahaan

Perbankan Pemerintah dan Swasta

Sehat

$Z>2,99$

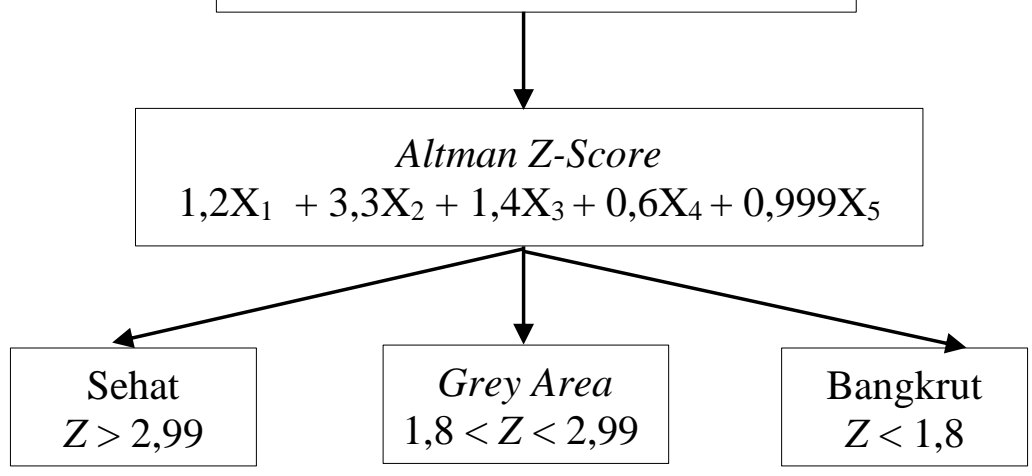

Hipotesis

$\mathrm{H}_{1}$ : Bahwa menurut Altman ZScore, perusahaan perbankan pemerintah dan swasta yang terdaftar di Bursa Efek Indonesia memiliki resiko kebangkrutan.

$\mathrm{H}_{2}$ : Bahwa secara parsial Bank Permata memiliki tingkat resiko kebangkrutan paling besar.

\section{METODE PENELITIAN}

\section{Populasi dan Sampel}

Populasi adalah wilayah generalisasi yang terdiri atas objek atau subjek yang mempunyai kualitas dan karakteristik tertentu yang ditetapkan oleh peneliti untuk dipelajari dan kemudian ditarik kesimpulannya. Populasi dalam penelitian ini adalah perusahaan perbankan yang terdaftar di Bursa Efek Indonesia.

Sampel adalah bagian tertentu yang dipilih dari populasi. Metode pengambilan sampel yang digunakan adalah purposive sampling. Purposive sampling merupakan teknik untuk menentukan sampel penelitian dengan beberapa pertimbangan tertentu yang bertujuan agar data yang diperoleh nantinya bisa lebih representatif (Sugiyono, 2010).

Sampel dalam penelitian ini adalah Laporan Keuangan 10 perusahaan perbankan tahun 20062016 yang memiliki kriteria sebagai berikut:

a) Telah go public dan terdaftar di Bursa Efek Indonesia.

b) Berada diurutan 11 bank terbesar berdasarkan aset di Bursa Efek Indonesia pada tahun 2016.

c) Telah diaudit.

d) Telah terdaftar di Bursa Efek Indonesia sejak tahun 2005.

Bank-bank yang masuk dalam kriteria sampel penelitian dapat dilihat pada tabel berikut ini.

\section{Tabel 1}

\section{Daftar Nama Bank}

\section{Nama Perusahaan Perbankan}

\begin{tabular}{lcl}
\hline a. & \multicolumn{3}{l}{ Bank Pemerintah } \\
\hline 1. & BBNI & PT. Bank Negara Indonesia (Persero) Tbk \\
2. & BBRI & PT. Bank Rakyat Indonesia (Persero) Tbk \\
3. & BMRI & PT. Bank Mandiri (Persero) Tbk \\
\hline b. & Bank Swasta \\
\hline
\end{tabular}




\begin{tabular}{rrl} 
4. & BBCA & PT. Bank Central Asia Tbk \\
5. & BDMN & PT. Bank Danamon Indonesia Tbk \\
6. & BNGA & PT. Bank CIMB Niaga Tbk \\
7. & BNLI & PT. Bank Permata Tbk \\
8. & NISP & PT. Bank OCBC NISP Tbk \\
9. & PNBN & PT. Bank Pan Indonesia Tbk \\
10. & BNII & PT. Bank Maybank Indonesia Tbk \\
\hline
\end{tabular}

Sumber: diolah peneliti

\section{Jenis dan Sumber Data}

Jenis data yang dikumpulkan dari penelitian ini adalah data sekunder. Data sekunder merupakan data yang dikumpulkan dari tangan kedua atau dari sumber lain yang telah tersedia sebelum penelitian dilakukan.

Sumber data dalam penulisan skripsi ini adalah dari berbagai sumber buku, jurnal dan penelitian terdahulu yang mendukung penelitian. Sedangkan untuk sumber data yang akan diolah dalam analisis penelitian adalah www.idx.co.id, situs web resmi Bursa Efek Indonesia dan situs masing-masing perusahaan perbankan yang akan dilakukan penelitian.

\section{Metode Analisis}

Metode analisis yang digunakan dalam penelitian ini adalah analisis deskriptif, yaitu teknik analisis data berbentuk tabel, grafik, dan selanjutnya dilakukan pengukuran.

\section{Analisis Laporan Keuangan}

Utari dkk (2014:53) menjelaskan bahwa analisis laporan keuangan ialah kegiatan membandingkan kinerja perusahaan dalam bentuk angka-angka keuangan dengan perusahaan sejenis atau dengan angka-angka keuangan periode sebelumnya. Pada penelitian ini akan dibahas mengenai prediksi kebangkrutan bank dengan menggunakan model Altman Z-Score yang di dalamnya terdapat rasiorasio keuangan diantaranya rasio likuiditas, rasio profitabilitas dan rasio aktivitas.

\section{HASIL ANALISIS DAN PEMBAHASAN}

\section{Analisis}

Dari hasil perhitungan kelima rasio dikalikan dengan standar masing-masing sesuai dengan ketentuan Z-Score maka diperoleh hasil Z-Score untuk masing-masing perusahaan pada tahun 2006-2016 sebagai berikut.

Tabel 2

Hasil Z-Score pada Perusahaan Perbankan Tahun 2006

\begin{tabular}{cccccccc}
\hline No. & Kode Bank & $\mathbf{X}_{\mathbf{1}}$ & $\mathbf{X}_{\mathbf{2}}$ & $\mathbf{X}_{\mathbf{3}}$ & $\mathbf{X}_{\mathbf{4}}$ & $\mathbf{X}_{\mathbf{5}}$ & Z-Score \\
\hline 1. & BBNI & 0,086 & 0,055 & 0,023 & 0,096 & 0,105 & $\mathbf{0 , 3 6 6}$ \\
2. & BBRI & 0,150 & 0,126 & 0,067 & 0,275 & 0,146 & $\mathbf{0 , 7 6 5}$ \\
3. & BMRI & 0,125 & 0,035 & 0,032 & 0,149 & 0,107 & $\mathbf{0 , 4 4 8}$ \\
4. & BBCA & 0,094 & 0,113 & 0,092 & 0,242 & 0,109 & $\mathbf{0 , 6 5 1}$
\end{tabular}




\begin{tabular}{cccccccc} 
5. & BDMN & 0,150 & 0,085 & 0,089 & 0,276 & 0,154 & $\mathbf{0 , 7 5 4}$ \\
6. & BNGA & 0,118 & 0,066 & 0,045 & 0,159 & 0,127 & $\mathbf{0 , 5 1 5}$ \\
7. & BNLI & 0,087 & 0,040 & $-0,156$ & 0,119 & 0,136 & $\mathbf{0 , 2 2 5}$ \\
8. & NISP & 0,115 & 0,045 & 0,063 & 0,116 & 0,114 & $\mathbf{0 , 4 5 3}$ \\
9. & PNBN & 0,146 & 0,085 & 0,056 & 0,206 & 0,115 & $\mathbf{0 , 6 0 8}$ \\
10. & BNII & 0,176 & 0,046 & 0,044 & 0,145 & 0,136 & $\mathbf{0 , 5 4 7}$ \\
\hline
\end{tabular}

Sumber: Data diolah peneliti

Dengan melihat hasil Z-Score di atas, terlihat bahwa 10 perusahaan perbankan berada dalam kondisi

ancaman kebangkrutan menurut Altman ditandai dengan nilai $Z$ Score yang berada di bawah 1,81

Tabel 3

Hasil Z-Score pada Perusahaan Perbankan Tahun 2007

\begin{tabular}{cccccccc}
\hline No. & $\begin{array}{c}\text { Kode } \\
\text { Bank }\end{array}$ & X1 & X2 & X3 & X4 & X5 & Z-Score \\
\hline 1. & BBNI & 0,103 & 0,027 & 0,016 & 0,109 & 0,104 & $\mathbf{0 , 3 5 8}$ \\
2. & BBRI & 0,139 & 0,126 & 0,069 & 0,297 & 0,123 & $\mathbf{0 , 7 5 4}$ \\
3. & BMRI & 0,121 & 0,065 & 0,039 & 0,151 & 0,085 & $\mathbf{0 , 4 6 1}$ \\
4. & BBCA & 0,091 & 0,097 & 0,089 & 0,237 & 0,088 & $\mathbf{0 , 6 3 8}$ \\
5. & BDMN & 0,153 & 0,122 & 0,103 & 0,307 & 0,160 & $\mathbf{0 , 8 4 7}$ \\
6. & BNGA & 0,112 & 0,062 & 0,047 & 0,134 & 0,104 & $\mathbf{0 , 4 6 0}$ \\
\hline 7. & BNLI & 0,112 & 0,062 & $-0,133$ & 0,117 & 0,130 & $\mathbf{0 , 2 8 8}$ \\
8. & NISP & 0,120 & 0,040 & 0,065 & 0,123 & 0,102 & $\mathbf{0 , 4 4 9}$ \\
9. & PNBN & 0,123 & 0,081 & 0,065 & 0,179 & 0,092 & $\mathbf{0 , 5 4 0}$ \\
10. & BNII & 0,179 & 0,023 & 0,046 & 0,167 & 0,122 & $\mathbf{0 , 5 3 6}$ \\
\hline
\end{tabular}

Sumber: Data diolah peneliti

Dengan melihat hasil Z-Score di atas, terlihat bahwa 10 perusahaan perbankan berada dalam kondisi

bangkrut menurut Altman Z-Score ditandai dengan nilai $Z$-Score yang berada di bawah 1,81 .

\section{Tabel 4}

Hasil Z-Score pada Perusahaan Perbankan Tahun 2008

\begin{tabular}{cccccccc}
\hline No. & $\begin{array}{l}\text { Kode } \\
\text { Bank }\end{array}$ & $\mathbf{X}_{\mathbf{1}}$ & $\mathbf{X}_{\mathbf{2}}$ & $\mathbf{X}_{\mathbf{3}}$ & $\mathbf{X}_{\mathbf{4}}$ & $\mathbf{X}_{\mathbf{5}}$ & $\begin{array}{c}\boldsymbol{Z} \text { - } \\
\text { Score }\end{array}$ \\
\hline 1. & BBNI & 0,083 & 0,032 & 0,018 & 0,033 & 0,100 & $\mathbf{0 , 2 6 6}$ \\
2. & BBRI & 0,109 & 0,119 & 0,076 & 0,151 & 0,124 & $\mathbf{0 , 5 8 0}$ \\
3. & BMRI & 0,105 & 0,074 & 0,051 & 0,077 & 0,089 & $\mathbf{0 , 3 9 7}$ \\
4. & BBCA & 0,098 & 0,104 & 0,105 & 0,216 & 0,094 & $\mathbf{0 , 6 1 7}$ \\
5. & BDMN & 0,108 & 0,082 & 0,091 & 0,161 & 0,163 & $\mathbf{0 , 6 0 6}$ \\
6. & BNGA & 0,127 & 0,035 & 0,035 & 0,076 & 0,111 & $\mathbf{0 , 3 8 3}$ \\
7. & BNLI & 0,031 & 0,046 & $-0,072$ & 0,046 & 0,100 & $\mathbf{0 , 1 5 1}$ \\
8. & NISP & 0,113 & 0,044 & 0,072 & 0,080 & 0,095 & $\mathbf{0 , 4 0 4}$
\end{tabular}




\begin{tabular}{cccccccc} 
9. & PNBN & 0,136 & 0,059 & 0,084 & 0,125 & 0,102 & $\mathbf{0 , 5 0 6}$ \\
10. & BNII & 0,119 & 0,037 & 0,048 & 0,214 & 0,127 & $\mathbf{0 , 5 4 5}$ \\
\hline
\end{tabular}

Sumber: Data diolah peneliti

Dengan melihat hasil Z-Score di atas, terlihat bahwa 10 perusahaan perbankan berada dalam kondisi bangkrut menurut Altman Z-Score ditandai dengan nilai $Z$-Score yang berada di bawah 1,81 .

\section{Tabel 5}

Hasil Z-Score pada Perusahaan Perbankan Tahun 2009

\begin{tabular}{cccccccc}
\hline No. & $\begin{array}{c}\text { Kode } \\
\text { Bank }\end{array}$ & $\mathbf{X}_{\mathbf{1}}$ & $\mathbf{X}_{\mathbf{2}}$ & $\mathbf{X}_{\mathbf{3}}$ & $\mathbf{X}_{\mathbf{4}}$ & $\mathbf{X}_{\mathbf{5}}$ & $\begin{array}{c}Z-~ \\
\text { Score }\end{array}$ \\
\hline 1. & BBNI & 0,093 & 0,050 & 0,042 & 0,106 & 0,104 & $\mathbf{0 , 3 9 6}$ \\
2. & BBRI & 0,115 & 0,103 & 0,079 & 0,195 & 0,122 & $\mathbf{0 , 6 1 4}$ \\
3. & BMRI & 0,127 & 0,091 & 0,064 & 0,164 & 0,096 & $\mathbf{0 , 5 4 2}$ \\
4. & BBCA & 0,102 & 0,105 & 0,112 & 0,282 & 0,097 & $\mathbf{0 , 6 9 7}$ \\
5. & BDMN & 0,139 & 0,079 & 0,110 & 0,271 & 0,195 & $\mathbf{0 , 7 9 4}$ \\
6. & BNGA & 0,141 & 0,067 & 0,048 & 0,106 & 0,118 & $\mathbf{0 , 4 7 9}$ \\
7. & BNLI & 0,078 & 0,045 & $-0,057$ & 0,073 & 0,122 & $\mathbf{0 , 2 6 1}$ \\
8. & NISP & 0,124 & 0,055 & 0,083 & 0,079 & 0,104 & $\mathbf{0 , 4 4 5}$ \\
9. & PNBN & 0,148 & 0,060 & 0,086 & 0,164 & 0,107 & $\mathbf{0 , 5 6 4}$ \\
\hline 10. & BNII & 0,114 & 0,002 & 0,041 & 0,178 & 0,128 & $\mathbf{0 , 4 6 3}$
\end{tabular}

Sumber: Data diolah peneliti

Dengan melihat hasil Z-Score di atas, terlihat bahwa 10 perusahaan perbankan berada dalam kondisi bangkrut menurut Altman Z-Score ditandai dengan nilai Z-Score yang berada di bawah 1,81 .

\section{Tabel 6}

Hasil Z-Score pada Perusahaan Perbankan Tahun 2010

\begin{tabular}{cccccccc}
\hline $\begin{array}{l}\text { N } \\
\text { o. }\end{array}$ & $\begin{array}{c}\text { Kode } \\
\text { Bank }\end{array}$ & $\mathbf{X}_{\mathbf{1}}$ & $\mathbf{X}_{\mathbf{2}}$ & $\mathbf{X}_{\mathbf{3}}$ & $\mathbf{X}_{\mathbf{4}}$ & $\mathbf{X}_{\mathbf{5}}$ & Z-Score \\
\hline 1. & BBNI & 0,083 & 0,032 & 0,018 & 0,033 & 0,100 & $\mathbf{0 , 2 6 6}$ \\
2. & BBRI & 0,109 & 0,119 & 0,076 & 0,151 & 0,124 & $\mathbf{0 , 5 8 0}$ \\
3. & BMRI & 0,105 & 0,074 & 0,051 & 0,077 & 0,089 & $\mathbf{0 , 3 9 7}$ \\
4. & BBCA & 0,098 & 0,104 & 0,105 & 0,216 & 0,094 & $\mathbf{0 , 6 1 7}$ \\
5. & BDMN & 0,108 & 0,082 & 0,091 & 0,161 & 0,163 & $\mathbf{0 , 6 0 6}$ \\
6. & BNGA & 0,127 & 0,035 & 0,035 & 0,076 & 0,111 & $\mathbf{0 , 3 8 3}$ \\
7. & BNLI & 0,031 & 0,046 & $-0,072$ & 0,046 & 0,100 & $\mathbf{0 , 1 5 1}$ \\
8. & NISP & 0,113 & 0,044 & 0,072 & 0,080 & 0,095 & $\mathbf{0 , 4 0 4}$ \\
9. & PNBN & 0,136 & 0,059 & 0,084 & 0,125 & 0,102 & $\mathbf{0 , 5 0 6}$ \\
10 & BNII & 0,119 & 0,037 & 0,048 & 0,214 & 0,127 & $\mathbf{0 , 5 4 5}$ \\
. & & & & & & & \\
\hline
\end{tabular}

Sumber: Data diolah peneliti 
Dengan melihat hasil Z-Score di atas, terlihat bahwa 10 perusahaan perbankan berada dalam kondisi bangkrut menurut Altman Z-Score ditandai dengan nilai Z-Score yang berada di bawah 1,81 .

Tabel 7

Hasil Z-Score pada Perusahaan Perbankan Tahun 2011

\begin{tabular}{cccccccc}
\hline No. & $\begin{array}{c}\text { Kode } \\
\text { Bank }\end{array}$ & $\mathbf{X}_{\mathbf{1}}$ & $\mathbf{X}_{\mathbf{2}}$ & $\mathbf{X}_{\mathbf{3}}$ & $\mathbf{X}_{\mathbf{4}}$ & $\mathbf{X}_{\mathbf{5}}$ & Z-Score \\
\hline 1. & BBNI & 0,144 & 0,082 & 0,068 & 0,163 & 0,095 & $\mathbf{0 , 5 5 1}$ \\
2. & BBRI & 0,139 & 0,132 & 0,119 & 0,238 & 0,115 & $\mathbf{0 , 7 4 2}$ \\
3. & BMRI & 0,152 & 0,099 & 0,085 & 0,193 & 0,098 & $\mathbf{0 , 6 2 7}$ \\
4. & BBCA & 0,125 & 0,118 & 0,134 & 0,348 & 0,083 & $\mathbf{0 , 8 0 8}$ \\
5. & BDMN & 0,198 & 0,106 & 0,120 & 0,178 & 0,155 & $\mathbf{0 , 7 5 6}$ \\
6. & BNGA & 0,151 & 0,087 & 0,075 & 0,124 & 0,102 & $\mathbf{0 , 5 3 9}$ \\
7. & BNLI & 0,122 & 0,051 & 0,000 & 0,080 & 0,086 & $\mathbf{0 , 3 3 8}$ \\
8. & NISP & 0,139 & 0,055 & 0,078 & 0,086 & 0,081 & $\mathbf{0 , 4 3 9}$ \\
9. & PNBN & 0,162 & 0,072 & 0,095 & 0,104 & 0,097 & $\mathbf{0 , 5 2 9}$ \\
10. & BNII & 0,118 & 0,034 & 0,041 & 0,163 & 0,107 & $\mathbf{0 , 4 6 4}$ \\
\hline
\end{tabular}

Sumber: Data diolah peneliti

Dengan melihat hasil Z-Score di atas, terlihat bahwa 10 perusahaan perbankan berada dalam kondisi bangkrut menurut Altman Z-Score ditandai dengan nilai Z-Score yang berada di bawah 1,81 .

Tabel 8

Hasil Z-Score pada Perusahaan Perbankan Tahun 2012

\begin{tabular}{cccccccc}
\hline No. & $\begin{array}{c}\text { Kode } \\
\text { Bank }\end{array}$ & $\mathbf{X}_{\mathbf{1}}$ & $\mathbf{X}_{\mathbf{2}}$ & $\mathbf{X}_{\mathbf{3}}$ & $\mathbf{X}_{\mathbf{4}}$ & $\mathbf{X}_{\mathbf{5}}$ & Z-Score \\
\hline 1. & BBNI & 0,153 & 0,088 & 0,084 & 0,143 & 0,093 & $\mathbf{0 , 5 6 1}$ \\
2. & BBRI & 0,148 & 0,143 & 0,140 & 0,211 & 0,105 & $\mathbf{0 , 7 4 7}$ \\
3. & BMRI & 0,157 & 0,106 & 0,101 & 0,203 & 0,094 & $\mathbf{0 , 6 6 2}$ \\
4. & BBCA & 0,129 & 0,109 & 0,144 & 0,344 & 0,080 & $\mathbf{0 , 8 0 6}$ \\
5. & BDMN & 0,207 & 0,116 & 0,137 & 0,255 & 0,158 & $\mathbf{0 , 8 7 4}$ \\
6. & BNGA & 0,152 & 0,097 & 0,094 & 0,095 & 0,096 & $\mathbf{0 , 5 3 3}$ \\
7. & BNLI & 0,142 & 0,047 & 0,015 & 0,071 & 0,078 & $\mathbf{0 , 3 5 3}$ \\
8. & NISP & 0,150 & 0,051 & 0,074 & 0,112 & 0,073 & $\mathbf{0 , 4 5 9}$ \\
9. & PNBN & 0,161 & 0,067 & 0,099 & 0,069 & 0,089 & $\mathbf{0 , 4 8 7}$ \\
10. & BNII & 0,129 & 0,048 & 0,048 & 0,129 & 0,100 & $\mathbf{0 , 4 5 4}$ \\
\hline Sumb
\end{tabular}

Sumber: Data diolah peneliti

Dengan melihat hasil Z-Score di atas, terlihat bahwa 10 perusahaan perbankan berada dalam kondisi bangkrut menurut Altman Z-Score ditandai dengan nilai Z-Score yang berada di bawah 1,81. 
Tabel 9

Hasil Z-Score pada Perusahaan Perbankan Tahun 2013

\begin{tabular}{cccccccc}
\hline No. & $\begin{array}{c}\text { Kode } \\
\text { Bank }\end{array}$ & $\mathbf{X}_{\mathbf{1}}$ & $\mathbf{X}_{\mathbf{2}}$ & $\mathbf{X}_{\mathbf{3}}$ & $\mathbf{X}_{\mathbf{4}}$ & $\mathbf{X}_{\mathbf{5}}$ & Z-Score \\
\hline 1. & BBNI & 0,149 & 0,096 & 0,098 & 0,130 & 0,093 & $\mathbf{0 , 5 6 6}$ \\
2. & BBRI & 0,154 & 0,147 & 0,158 & 0,196 & 0,108 & $\mathbf{0 , 7 6 4}$ \\
3. & BMRI & 0,156 & 0,108 & 0,114 & 0,171 & 0,097 & $\mathbf{0 , 6 4 6}$ \\
4. & BBCA & 0,144 & 0,118 & 0,156 & 0,327 & 0,084 & $\mathbf{0 , 8 2 9}$ \\
5. & BDMN & 0,199 & 0,099 & 0,135 & 0,142 & 0,144 & $\mathbf{0 , 7 2 2}$ \\
6. & BNGA & 0,152 & 0,088 & 0,112 & 0,072 & 0,094 & $\mathbf{0 , 5 1 7}$ \\
7. & BNLI & 0,136 & 0,046 & 0,026 & 0,053 & 0,080 & $\mathbf{0 , 3 4 0}$ \\
8. & NISP & 0,181 & 0,052 & 0,077 & 0,101 & 0,072 & $\mathbf{0 , 4 8 3}$ \\
9. & PNBN & 0,155 & 0,065 & 0,110 & 0,066 & 0,087 & $\mathbf{0 , 4 8 3}$ \\
10. & BNII & 0,115 & 0,051 & 0,053 & 0,089 & 0,088 & $\mathbf{0 , 3 9 7}$ \\
\hline
\end{tabular}

Sumber: Data diolah peneliti

Dengan melihat hasil Z-Score bangkrut menurut Altman Z-Score di atas, terlihat bahwa 10 perusahaan perbankan berada dalam kondisi ditandai dengan nilai Z-Score yang berada di bawah 1,81 .

Tabel 10

Hasil Z-Score pada Perusahaan Perbankan Tahun 2014

\begin{tabular}{cccccccc}
\hline No. & Kode Bank & $\mathbf{X}_{\mathbf{1}}$ & $\mathbf{X}_{\mathbf{2}}$ & $\mathbf{X}_{\mathbf{3}}$ & $\mathbf{X}_{\mathbf{4}}$ & $\mathbf{X}_{\mathbf{5}}$ & Z-Score \\
\hline 1. & BBNI & 0,173 & 0,107 & 0,118 & 0,192 & 0,106 & $\mathbf{0 , 6 9 6}$ \\
2. & BBRI & 0,139 & 0,127 & 0,155 & 0,245 & 0,105 & $\mathbf{0 , 7 7 1}$ \\
3. & BMRI & 0,153 & 0,100 & 0,121 & 0,188 & 0,101 & $\mathbf{0 , 6 6 4}$ \\
4. & BBCA & 0,158 & 0,124 & 0,172 & 0,407 & 0,096 & $\mathbf{0 , 9 5 6}$ \\
5. & BDMN & 0,203 & 0,060 & 0,136 & 0,159 & 0,147 & $\mathbf{0 , 7 0 9}$ \\
6. & BNGA & 0,148 & 0,045 & 0,119 & 0,062 & 0,098 & $\mathbf{0 , 4 7 2}$ \\
7. & BNLI & 0,138 & 0,036 & 0,033 & 0,064 & 0,095 & $\mathbf{0 , 3 6 7}$ \\
8. & NISP & 0,185 & 0,057 & 0,091 & 0,106 & 0,084 & $\mathbf{0 , 5 2 3}$ \\
9. & PNBN & 0,170 & 0,070 & 0,123 & 0,113 & 0,101 & $\mathbf{0 , 5 7 3}$ \\
10. & BNII & 0,141 & 0,022 & 0,059 & 0,066 & 0,107 & $\mathbf{0 , 3 9 4}$ \\
\hline
\end{tabular}

Sumber: Data diolah peneliti

Dengan melihat hasil Z-Score di atas, terlihat bahwa 10 perusahaan perbankan berada dalam kondisi bangkrut menurut Altman Z-Score ditandai dengan nilai Z-Score yang berada di bawah 1,81 
Tabel 11

Hasil Z-Score pada Perusahaan Perbankan Tahun 2015

\begin{tabular}{cccccccc}
\hline No. & Kode Bank & $\mathbf{X}_{\mathbf{1}}$ & $\mathbf{X}_{\mathbf{2}}$ & $\mathbf{X}_{\mathbf{3}}$ & $\mathbf{X}_{\mathbf{4}}$ & $\mathbf{X}_{\mathbf{5}}$ & Z-Score \\
\hline 1. & BBNI & 0,152 & 0,074 & 0,114 & 0,130 & 0,096 & $\mathbf{0 , 5 6 7}$ \\
2. & BBRI & 0,146 & 0,122 & 0,170 & 0,221 & 0,111 & $\mathbf{0 , 7 7 1}$ \\
3. & BMRI & 0,159 & 0,096 & 0,137 & 0,164 & 0,109 & $\mathbf{0 , 6 6 5}$ \\
4. & BBCA & 0,170 & 0,126 & 0,193 & 0,390 & 0,099 & $\mathbf{0 , 9 7 8}$ \\
5. & BDMN & 0,220 & 0,058 & 0,154 & 0,120 & 0,150 & $\mathbf{0 , 7 0 2}$ \\
6. & BNGA & 0,137 & 0,008 & 0,119 & 0,043 & 0,100 & $\mathbf{0 , 4 0 7}$ \\
7. & BNLI & 0,140 & 0,005 & 0,035 & 0,041 & 0,100 & $\mathbf{0 , 3 2 2}$ \\
8. & NISP & 0,170 & 0,055 & 0,095 & 0,084 & 0,084 & $\mathbf{0 , 4 8 8}$ \\
9. & PNBN & 0,140 & 0,044 & 0,127 & 0,078 & 0,098 & $\mathbf{0 , 5 1 6}$ \\
10. & BNII & 0,137 & 0,032 & 0,063 & 0,049 & 0,105 & $\mathbf{0 , 3 8 7}$ \\
\hline
\end{tabular}

Sumber: Data diolah peneliti

Dengan melihat hasil Z-Score di atas, terlihat bahwa 10 perusahaan perbankan berada dalam kondisi

bangkrut menurut Altman Z-Score ditandai dengan nilai Z-Score yang berada di bawah 1,81 .

\section{Tabel 12}

Hasil Z-Score pada Perusahaan Perbankan Tahun 2016

\begin{tabular}{cccccccc}
\hline No. & $\begin{array}{c}\text { Kode } \\
\text { Bank }\end{array}$ & $\mathbf{X}_{\mathbf{1}}$ & $\mathbf{X}_{\mathbf{2}}$ & $\mathbf{X}_{\mathbf{3}}$ & $\mathbf{X}_{\mathbf{4}}$ & $\mathbf{X}_{\mathbf{5}}$ & Z-Score \\
\hline 1. & BBNI & 0,150 & 0,078 & 0,118 & 0,120 & 0,098 & $\mathbf{0 , 5 6 5}$ \\
2. & BBRI & 0,153 & 0,112 & 0,175 & 0,202 & 0,114 & $\mathbf{0 , 7 5 6}$ \\
\hline 3. & BMRI & 0,147 & 0,059 & 0,131 & 0,183 & 0,101 & $\mathbf{0 , 6 2 1}$ \\
4. & BBCA & 0,178 & 0,126 & 0,204 & 0,407 & 0,095 & $\mathbf{1 , 0 0 9}$ \\
5. & BDMN & 0,254 & 0,083 & 0,183 & 0,155 & 0,152 & $\mathbf{0 , 8 2 8}$ \\
6. & BNGA & 0,148 & 0,039 & 0,129 & 0,061 & 0,098 & $\mathbf{0 , 4 7 6}$ \\
7. & BNLI & 0,145 & $-0,172$ & $-0,017$ & 0,051 & 0,101 & $\mathbf{0 , 1 0 8}$ \\
8. & NISP & 0,159 & 0,056 & 0,101 & 0,120 & 0,084 & $\mathbf{0 , 5 2 0}$ \\
9. & PNBN & 0,177 & 0,055 & 0,134 & 0,066 & 0,094 & $\mathbf{0 , 5 2 6}$ \\
10. & BNII & 0,192 & 0,052 & 0,076 & 0,094 & 0,094 & $\mathbf{0 , 5 0 8}$
\end{tabular}

Sumber: Data diolah peneliti

Dengan melihat hasil Z-Score di atas, terlihat bahwa 10 perusahaan perbankan berada dalam kondisi bangkrut menurut Altman Z-Score ditandai dengan nilai Z-Score yang berada di bawah 1,81 .

\section{Pembahasan}

Setelah perhitungan terhadap 5 (lima) variabel, indeks Z-Score secara keseluruhan pada 10 perusahaan perbankan di Bursa Efek Indonesia yang menjadi objek penelitian dari tahun 2006 sampai dengan tahun 2016 dengan menggunakan persamaan:

$Z=1,2 \mathrm{X}_{1}+3,3 \mathrm{X}_{2}+1,4 \mathrm{X}_{3}+0,6 \mathrm{X}_{4}+$ $0,999 X_{5}$

Keterangan: 
$\mathrm{Z}=$ bankruptcy index / overall index

(indeks keseluruhan)

$\mathrm{X}_{1}=$ working capital to total assets

$\mathrm{X}_{2}=$ earnings before interest and

taxes to total assets

$\mathrm{X}_{3}=$ retained earnings to total

assets

$\mathrm{X}_{4}=$ market value of equity to book value of total debt

$\mathrm{X}_{5}=$ sales to total assets
Dengan nilai cut-off:

$Z<1,8 \quad=\quad$ menghadapi ancaman kebangkrutan

$1,8<Z<2,99=\quad$ grey area $Z>2,99=$ tidak bangkrut atau sehat

Dari hasil perhitungan di atas, diperoleh persentase kategori berdasarkan bankruptcy index sesuai dengan tabel berikut ini.

Tabel 13

Persentase Prediksi Kebangkrutan Perusahaan Perbankan

Tahun 2006-2016

\begin{tabular}{|c|c|c|c}
\hline \multirow{2}{*}{ Tahun } & \multicolumn{3}{|c}{ Prediksi Kebangkrutan } \\
\cline { 2 - 4 } & Bangkrut & Grey Area & Sehat \\
\hline 2006 & $100 \%$ & $0 \%$ & $0 \%$ \\
2007 & $100 \%$ & $0 \%$ & $0 \%$ \\
2008 & $100 \%$ & $0 \%$ & $0 \%$ \\
2010 & $100 \%$ & $0 \%$ & $0 \%$ \\
\hline 2011 & $100 \%$ & $0 \%$ & $0 \%$ \\
2012 & $100 \%$ & $0 \%$ & $0 \%$ \\
2013 & $100 \%$ & $0 \%$ & $0 \%$ \\
2014 & $100 \%$ & $0 \%$ & $0 \%$ \\
2015 & $100 \%$ & $0 \%$ & $0 \%$ \\
2016 & $100 \%$ & $0 \%$ & $0 \%$ \\
\hline \hline
\end{tabular}

Sumber: Data diola

Tabel 14

Rata-rata Bankruptcy Index pada PerusahaanPerbankan

Tahun 2006-2016

\begin{tabular}{clc}
\hline \multicolumn{1}{c}{ Tahun 2006-2016 } & \\
No. & \multicolumn{1}{c}{ Nama Perusahaan Perbankan } & $\overline{\mathbf{X}}$ \\
\hline 1. & PT. Bank Central Asia Tbk & 0,795 \\
2. & PT. Bank Danamon Indonesia Tbk & 0,766 \\
3. & PT. Bank Rakyat Indonesia (Persero) Tbk & 0,722 \\
4. & PT. Bank Mandiri (Persero) Tbk & 0,576 \\
5. & PT. Bank Pan Indonesia Tbk & 0,534 \\
6. & PT. Bank Negara Indonesia (Persero) Tbk & 0,498 \\
7. & PT. Bank Maybank Indonesia Tbk & 0,489 \\
8. & PT. Bank CIMB Niaga Tbk & 0,489 \\
9. & PT. Bank OCBC NISP Tbk & 0,467 \\
10. & PT. Bank Permata Tbk & 0,288 \\
\hline
\end{tabular}

Sumber: Data diolah peneliti 
Kesimpulan yang dapat ditarik dari data-data di atas adalah PT Bank Permata Tbk yang memiliki tingkat ancaman kebangkrutan paling besar di antara perusahaan perbankan lainnya yang menjadi objek dari penelitian ini (indeks Z-Score ratarata sebesar 0,288).

Menilik dari laporan tahunan dan laporan keuangan Bank Permata Tbk, menunjukkan retained earnings yang tidak stabil, bahkan mengalami minus. Begitu juga dengan beban operasional perusahaan yang semakin membengkak. Selain itu, beban operasional yang melambung pada tahun 2016 menyebabkan earnings before interest and taxes juga mengalami minus atau turun drastis sebesar 3.046,76\% (Gambar 4.5). Hal ini menunjukkan bahwa kondisi perusahaan dalam keadaan yang memprihatinkan. Kondisi ini diperkuat dengan adanya pengurangan jumlah karyawan pada tahun 2016 sebesar 393 orang atau turun $4,98 \%$.

Selain itu, grafik laporan keuangan Bank Permata dari tahun 2006 hingga tahun 2016 juga menunjukan tren negatif. Hal ini terlihat pada tahun 2006 hingga penghujung tahun 2014, bank ini mengalami kenaikan jumlah aset rata sebesar 22,72\%. Namun pada tahun 2015 sampai tahun 2016, pertumbuhan aset Bank Permata rata-rata sebesar $-5,42 \%$. Hal ini diperparah dengan perolehan laba ditahan dari tahun 2006 hingga tahun 2011 menunjukkan angka minus, lalu menjadi tren positif 4 (empat) tahun setelahnya dan kembali mengalami penurunan pada tahun 2016 ($143,63 \%)$.
Meskipun pertumbuhan aset rata-rata sebesar $17,09 \%$ dan jumlah aset dan laba ditahan menunjukkan trend negatif, nilai working capital Bank Permata menunjukkan tren fluktuatif yang berarti bahwa perusahaan belum mampu menggunakan kapitalisasinya dengan baik.

\section{PENUTUP \\ Kesimpulan}

Penelitian ini dilakukan untuk menilai tingkat kesehatan bank dengan menggunakan metode Altman Z-Score. Setelah dilakukan perhitungan terhadap lima variabel, perhitungan indeks Z-Score keseluruhan pada 10 (sepuluh) perusahaan perbankan di Indonesia selama 11 tahun mulai tahun 2006 hingga tahun 2016 menunjukkan bahwa:

1. Angka rata-rata tiap tahun indeks Z-Score pada PT. Bank Mandiri (Persero) Tbk dengan skor 0,576; PT. Bank Rakyat Indonesia (Persero) Tbk dengan skor 0,722; PT. Bank Central Asia Tbk dengan skor 0,795; PT. Bank Negara Indonesia (Persero) Tbk dengan skor 0,498; PT. Bank CIMB Niaga Tbk dengan skor 0,489; PT. Bank Danamon Indonesia Tbk dengan skor 0,766; PT. Bank Pan Indonesia Tbk dengan skor 0,534; PT. Bank Permata Tbk dengan skor 0,288; PT. Bank Maybank Indonesia Tbk dengan skor 0,489 ; serta PT. Bank OCBC NISP Tbk dengan skor 0,467 .

2. Selama periode penelitian, seluruh perusahaan perbankan di Indonesia berada dalam kondisi 
menghadapi

ancaman

kebangkrutan karena nilai $Z$ -

Score lebih kecil dari 1,81.

3. PT. Bank Permata Tbk merupakan perusahaan perbankan yang memiliki angka cut-off paling kecil sehingga perusahaan tersebut memiliki ancaman kebangkrutan paling besar.

\section{Saran}

Diharapkan manajemen bank harus memperhatikan besarnya rasio return on total assets. Besar-kecilnya rasio tersebut dapat memberikan gambaran mengenai keberlangsungan usaha perusahaan di masa yang akan datang, sehingga apabila terdapat indikasi kebangkrutan dapat diambil perbaikan kinerja. Selain itu, bagi kalangan dunia usaha diharapkan dapat mempertimbangkan untuk memakai metode alternatif, yaitu multivariate discriminant analysis dengan menggunakan rasio-rasio yang ada dalam metode Altman ZScore apabila akan melakukan analisis untuk mendeteksi kondisi finansial suatu perbankan.

Dalam menentukan kinerja perbankan, Bank Indonesia telah mempunyai alat ukur sendiri, sehingga diharapkan peneliti selanjutnya dapat melakukan analisis yang komprehensif dengan multivariate discriminant analysis antara rasio-rasio dalam model prediksi Altman Z-Score dengan alat ukur yang telah ditetapkan oleh Bank Indonesia.

\section{DAFTAR PUSTAKA}

Altman, Edward I. 1968. Financial Ratios, Discriminant

Analysis and The Prediction of Corporate Bankruptcy. The Journal of Finance. Vol. XXIII, September, 589-609

Bragg, Steven M. 2002. Business Ratios and Formulas: A Comprehensive Guide. John Wiley \& Sons, Inc., Hoboken, New Jersey

Darmawi, Herman. 2014. Manajemen Perbankan. Bumi Aksara: Jakarta

Herman. 2016. Manajemen Resiko Edisi 2. Bumi Aksara: Jakarta

Endri. 2009. Prediksi Kebangkrutan Bank Untuk Menghadapi dan Mengelola Perubahan Lingkungan Bisnis: Analisis Model Altman's Z-Score. Perbanas Quartely Review, Vol. 2, No. 1, Maret 2009. ISSN: 1978-9017

Haryetti. 2010. Analisis Financial Distress Untuk Memprediksi Risiko Kebangkrutan Perusahaan (Studi Kasus Pada Industri Perbankan di BEI). Jurnal Ekonomi, Vol. 18, No. 2, Juni 2010

Husnan, Suad., dan Enny Pudjiastuti. 2015.

Dasar-Dasar Manajemen Keuangan. UPP STIM YKPN: Yogyakarta

Kamal, ST. Ibrah Mustafa. 2012. Analisis Prediksi Kebangkrutan Pada 
Perusahaan Perbankan Go

Public di Bursa Efek Indonesia (dengan menggunakan model Altman-Z-Score). Skripsi Universitas Hasanuddin Makassar

Kartikawati, Sinta. 2008. Analisis ZScore Dalam Mengukur Kinerja Keuangan Untuk Memprediksi Kebangkrutan Pada Tujuh Perusahaan Manufaktur Di Bursa Efek Jakarta. Skripsi Fakultas Ekonomi Universitas Gunadarma

Kurniawati, Lintang., Nur Kholis. 2015. Analisis Model Prediksi Financial Distress Pada Perusahaan Perbankan Syariah di Indonesia. Syariah Paper Accounting FEB UMS. Surakarta, 2015. ISSN: 2460-0784

Kusdiana, Yayu. 2014. Analisis Model Camel dan Altman's Z-Score Dalam Memprediksi Kebangkrutan Bank Umum di Indonesia (Studi pada Bank Umum yang Tercatat di Bursa Efek Indonesia Tahun 20072011). Jurnal Tepak Manajemen Bisnis, Vol. VI, No. 1 Januari 2014, Pekanbaru, Januari 2014

Likumahua, Debby. 2013. Analisis Kebangkrutan Bank Terhadap Harga Saham pada Perusahaan Perbankan yang Terdaftar di Bursa Efek Indonesia. Benchmark, Vol. 2, No. 1 November
2013, Ambon, November

2013. ISSN: $2302-5298$

Lisdayanti, Agustya., Zeinia Siti Iqlima, dan Wanda Anindita. 2013. Analisis Potensi Kebangkrutan Bank yang Terdaftar di BEI Tahun 2012 dengan Menggunakan Model Altman Z-Score. Proceeding PESAT, Vol. 5 Oktober 2013, Bandung, 8-9 Oktober 2013. ISSN: $1858-2559$

Nurrudin, Ali. 2005. Analisis Prediksi Kebangkrutan Pada Perbankan Go Public di Bursa Efek Jakarta. Skripsi Universitas Negeri Semarang

Prabowo, Reza., dan Wibowo. 2015. Analisis Perbandingan Model Altman Z-Score, Zmijewski, dan Springate dalam Memprediksi Kebangkrutan Perusahaan Delisting di BEI Periode 2008-2013. Jurnal Akuntansi, Keuangan dan Perbankan, Vol. 1 No. 13, Juni 2015. ISSN: 2338-9753

Ramadhani, Ayu Suci, dan Niki Lukviarman. 2009. Perbandingan Analisis Prediksi Kebangkrutan Menggunakan Model Altman Pertama, Altman Revisi, dan Altman Modifikasi dengan Ukuran dan Umur Perusahaan Sebagai Variabel Penjelas (Studi Pada Perusahaan Manufaktur yang Terdaftar di Bursa Efek Indonesia). Jurnal Siasat Bisnis Fakultas 
Ekonomi Universitas Andalas, Vol. 13, No. 1, April 2009 Hal: 15-28

Sherbo, Andrew $\mathbf{J}$ dan Andrew $\mathbf{J}$ Smith. 2013. The Altman ZScore Bankruptcy Model at Age 45: Standing the Test of Time?.

American Bankruptcy Institute Journal, Alexandria Vol. 32, Edisi 11, Halaman 4041 dan 86, Desember 2013. ISSN: 19317522

Sudiyatno, Bambang, dan Elen Puspitasari. 2010. Tobin's $Q$ dan Altman Z-Score Sebagai Indikator Pengukuran Kinerja Perusahaan. Kajian Akuntansi Universitas Stikubank Semarang, Vol. 2, No. 1, Februari 2010. ISSN: 1979-4886

Sugiyono. 2016. Metode Penelitian Manajemen: Pendekatan: Kuantitatif, Kualitatif, Kombinasi (Mixed Methods), Penelitian Tindakan (Action Research), Penelitian Evaluasi. Alfabeta:

Bandung

Sunyoto, Danang. 2016. Metode Penelitian Akuntansi. Refika Aditama: Bandung

Tampubolon, Manahan P. 2013. Manajemen Keuangan (Finance Management). Mitra Wacana Media: Jakarta

Undang-Undang Republik Indonesia Nomor 10 Tahun 1998

Tentang Perubahan atas Undang-Undang Nomor 7 $\begin{array}{ll}\text { Tahun } & 1992 \quad \text { Tentang } \\ \text { Perbankan } & \end{array}$

Utami, Eristy Minda, dan Neneng Susanti. 2015. Analisis Kebangkrutan PT. Bank Central Asia (Persero) Tbk dan PT. Bank Negara Indonesia (Persero) Tbk Periode 2011-2013. Jurnal Akuntansi Bisnis dan Ekonomi, Vol. I, No. 2, September 2015. ISSN: 2460-030X

Utari, Dewi, Ari Purwanti, dan Darsono Prawironegoro. 2014. Manajemen Keuangan (Kajian Praktik dan Teori dalam Mengelola Keuangan Organisasi Perusahaan). Mitra Wacana Media: Jakarta 